\title{
Status of the stippled studfish Fundulus bifax, a killifish endemic to the Tallapoosa River basin, USA
}

\author{
Bruce Stallsmith* \\ Department of Biological Sciences, Shelby Center, University of Alabama in Huntsville, Huntsville, Alabama 35899, USA
}

\begin{abstract}
The stippled studfish Fundulus bifax, which is endemic to the Tallapoosa River system of Alabama and Georgia, USA, has been considered at risk due to habitat degradation. Requisite habitat for this species is clean water over clean sand in small or large streams. F. bifax is apparently extirpated in Georgia, and appears increasingly uncommon in Alabama. This has resulted in a global ranking of N2N3, imperiled/vulnerable, from NatureServe. In 2008, 24 Tallapoosa River drainage sites in Alabama were visited in an effort to document the current status of this species. Many of these were locations where the fish has been collected since 1980, as documented in the University of Alabama Ichthyology Collection. At least 1 individual was found in each of 6 different creek systems in Coosa, Elmore, Randolph, and Tallapoosa Counties. This is a contraction of what has been considered this species' range, and appears to be the result of habitat degradation. To examine genetic variation between existing populations, and between 2 closely related species, 852 bases of the mitochondrial cytochrome $b$ gene of 10 individuals were compared through neighbor-joining and Bayesian tree building, and through calculating genetic distance, $D$. Both analyses showed existing populations of $F$. bifax to be monophyletic, with low genetic variation between them. Neither of its putative closest relatives, F. catenatus and F. stellifer, was found to be more closely related to $F$. bifax. The future of the species is in doubt, with 6 disjunct populations being vulnerable to further habitat degradation and diminished gene flow.
\end{abstract}

KEY WORDS: Cytochrome $b \cdot$ Habitat degradation $\cdot$ Alabama

\section{INTRODUCTION}

The stippled studfish Fundulus bifax (Fundulidae) is a species considered to be in slow decline (NatureServe 2010). It is included among a group of stream species known as 'narrow endemics' that are susceptible to habitat alterations due to growing human populations (Warren et al. 2000). The conservation status of $F$. bifax is poorly documented. According to NatureServe (2010), the global status of $F$. bifax is N2N3, imperiled/vulnerable, and the Alabama state status is S2, imperiled, while the International Union for the Conservation of Nature (IUCN) places the species on the Red List with the status of Near Threatened based on local rarity and an apparent range of $5000 \mathrm{~km}^{2}$. The original range of the species was in the Piedmont of Alabama and
Georgia in the Tallapoosa River basin, USA (Fig. 1). Apparently, the species has been extirpated from Georgia and was last collected in the Little Tallapoosa River system in Carroll County in 1990 (Storey et al. 2003, see also http://georgiawildlife. com/sites/default/files/uploads/wildlife/nongame/pdf/ accounts/fishes/fundulus_bifax.pdf). In Alabama, the species is known from the Tallapoosa River basin in Coosa, Elmore, Randolph, and Tallapoosa Counties, along with 1 stream in the Coosa River basin immediately to the west in Elmore County (Boschung \& Mayden 2004). The species is found in mediumsized streams, typically along the edge of the current, and requires clean sand for successful reproduction, since spawning fish dive into the sand and deposit eggs that incubate there for several days until hatching (Scanlan 2008). 


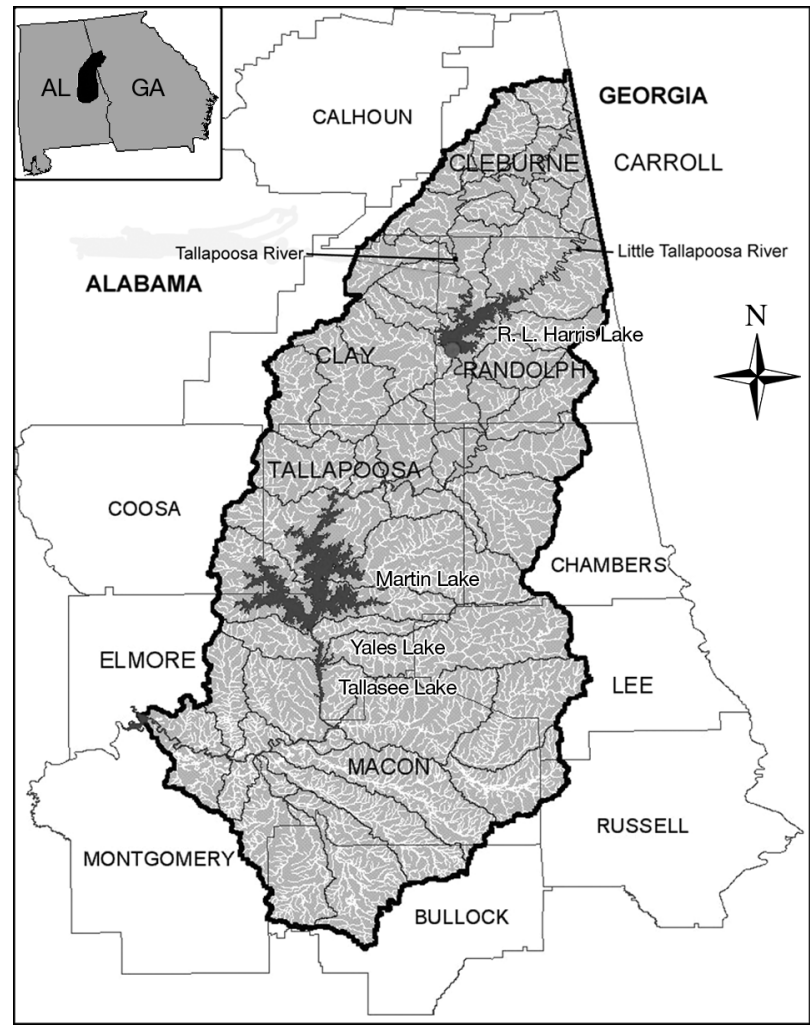

Fig. 1. Alabama section of the Tallapoosa River watershed with Alabama counties indicated. Carroll County in Georgia is also indicated as the site of 2 historic Fundulus bifax collection sites. Inset shows the entire Tallapoosa River Basin shared between Alabama and Georgia (USA)

Fundulus bifax is part of the studfish clade, subgenus Xenisma, with 5 extant and 1 extinct species. This clade is considered to be monophyletic based on morphological data (Cashner et al. 1992). F. bifax was formerly included in F. stellifer until it was described as a species in 1988 based on differences in breeding coloration and pigmentation patterns (Cashner et al. 1988). Allozyme data showed F. bifax to be more closely related to $F$. catenatus, even though the range of $F$. stellifer immediately abuts that of $F$. bifax, while the nearest populations of $F$. catenatus are $\sim 200 \mathrm{~km}$ to the north (Cashner et al. 1992).

The current project has 2 linked parts. The first part was intended primarily as a presence/absence survey of Fundulus bifax at historic location sites in Alabama based on holdings of the University of Alabama Ichthyology Collection (UAIC) in Tuscaloosa, Alabama. The Alabama section represents most of the historic range and may currently be the entire range. The second part of the project was to characterize the genetic diversity of $F$. bifax at the cytochrome $b$ locus of mitochondrial DNA, as well as its relationship with its 2 closest relatives, F. catenatus and F. stellifer.

\section{MATERIALS AND METHODS}

\section{Stream survey}

The UAIC provided a list of known Fundulus bifax collection sites based on their holdings. Fish collection was attempted at these sites in the Tallapoosa River basin both to ascertain the continued presence of the species at the site, and to collect specimens for DNA extraction. Streams were sampled using a $3.5 \times$ $1.3 \mathrm{~m}$ seine with $3 \mathrm{~mm}$ mesh. At each site, $200 \mathrm{~m}$ of stream were sampled, if accessible. Captured fish were sacrificed immediately after capture with tricaine methanesulfonate (MS-222) and transferred to $95 \%$ ethanol. Individuals from Sofkahatchee Creek were provided by Joseph Scanlan.

Streams in the Alabama section of the Tallapoosa River basin with no historic record of Fundulus bifax collection were also sampled to determine the full range of the species. In particular, streams in Cleburne County, Alabama, to the north of historic collection sites in Alabama were sampled, since this area is where both the Tallapoosa and Little Tallapoosa Rivers enter Alabama from Carroll County, Georgia, where F. bifax has been found.

\section{Extraction, amplification, and sequencing of DNA}

DNA was extracted from white muscle using the E.Z.N.A. Tissue DNA Kit (Omega Bio-Tek), following the manufacturer's instructions for the Tissue DNASpin Protocol. Amplification of extracted DNA via polymerase chain reaction (PCR) was done by Oblique Bio of Huntsville, Alabama, using an ABI 9700 with a 96 -well gold block. The PCR conditions consisted of $94^{\circ} \mathrm{C}$ for $5 \mathrm{~min}, 25$ cycles of $94^{\circ} \mathrm{C}$ for $30 \mathrm{~s}$, $50^{\circ} \mathrm{C}$ for $10 \mathrm{~s}$, and $72^{\circ} \mathrm{C}$ for $45 \mathrm{~s}$, with a final extension of $7 \mathrm{~min}$ at $72^{\circ} \mathrm{C}$. PCR reaction reagents and volumes are proprietary information of Oblique Bio. Sequencing reactions were performed on an ABI 9700 with a 384 dual block. Sequence detection was performed on an ABI 3730xL system using a $50 \mathrm{~cm}$ array. Sequencing conditions were $96^{\circ} \mathrm{C}$ for $5 \mathrm{~min}, 10$ cycles of $96^{\circ} \mathrm{C}$ for $10 \mathrm{~s}, 50^{\circ} \mathrm{C}$ for $5 \mathrm{~s}$, and $60^{\circ} \mathrm{C}$ for $1 \mathrm{~min} 15 \mathrm{~s}$, followed by 10 cycles of $96^{\circ} \mathrm{C}$ for $10 \mathrm{~s}, 50^{\circ} \mathrm{C}$ for $5 \mathrm{~s}$, and $60^{\circ} \mathrm{C}$ for $1 \mathrm{~min} 45 \mathrm{~s}$, followed by 10 cycles of $96^{\circ} \mathrm{C}$ for $10 \mathrm{~s}, 50^{\circ} \mathrm{C}$ for $5 \mathrm{~s}$, and $60^{\circ} \mathrm{C}$ for $2 \min 15 \mathrm{~s}$. The following 2 primers were used for both PCR amplifica- 
tion of the mitochondrial cytochrome $b$ locus and sequencing of the PCR amplification product: L14724, 5'-CGA AGC TTG ATA TGA AAA ACC ATC GTT G-3' (Pääbo 1990) and H15915, 5'-AAC TGC CAG TCA TCT CCG GTA CAA GAC-3' (Irwin et al. 1991).

\section{Analysis of DNA sequences and tree building}

DNA sequences were examined for apparent errors such as gaps, and aligned with other sequences using Geneious Align in Geneious Pro v. 4.6.2 (Biomatters). Phylogenetic trees were built using Geneious. Neighbor-joining was used as a tree-building method with the Hasegawa-Kishino-Yana (HKY) genetic distance model with 1000 bootstrap resamples. Bayesian inference was also used to build a phylogenetic tree using MrBayes with the GTR nucleotide substitution method, gamma rate variation, a chain length of 1.1 million generations beginning with random trees and a subsampling frequency of 200 (Huelsenbeck \& Ronquist 2001). To ensure accurate convergence, the first 100000 generations were treated as burn-in and discarded. The remaining trees were used to build a $50 \%$ majority rule consensus tree. Molecular Evolutionary Genetics Analysis (MEGA) v. 5.1 was used to calculate both genetic distance $(D)$ between individual sequences and the discrete gamma distribution, $\alpha$, a maximum likelihood estimate of the gamma parameter for site rates (Tamura et al. 2011).

\section{RESULTS}

\section{Stream survey}

Fundulus bifax was found at 8 of 13 historic sites sampled between February and July 2008 (Table 1 and interactive map in the supplement at www. int-res.com/articles/suppl/n020p019_supp/). Three of these sites were in the Hillabee Creek system (including Broken Arrow Creek), although the species was not found in Josie Leg Creek, a tributary of Hillabee Creek. The downstream site in Channahatchee Creek produced a single fish, while the

Table 1. Fundulus bifax. Stream survey results reported as present or absent; ease of capture is rated on a scale of 1 to 5, with 1 being easy and 5 being difficult. Sites are broken down into sites where the species has previously been reported, and those within its reported range with no record of the species. Both sections are organized by county in alphabetical order

\begin{tabular}{|c|c|c|c|c|c|}
\hline Site & County & $\begin{array}{l}\text { Latitude } \\
\qquad\left({ }^{\circ} \mathrm{N}\right)\end{array}$ & $\begin{array}{l}\text { Longitude } \\
\qquad\left({ }^{\circ} \mathrm{W}\right)\end{array}$ & Present? & $\begin{array}{l}\text { Ease of } \\
\text { capture }\end{array}$ \\
\hline \multicolumn{6}{|l|}{ Sites with previous collections } \\
\hline Elkahatchee Creek at State Route 22 & Coosa & 32.9050 & 86.0103 & Yes & 2 \\
\hline Gold Branch at State Route 63 & Elmore & 32.6929 & 86.0071 & No & \\
\hline Channahatchee Creek at Highway 63 & Elmore & 32.6697 & 86.0373 & No & \\
\hline Channahatchee Creek at Highway 229 & Elmore & 32.6501 & 85.9469 & Yes & 5 \\
\hline Sofkahatchee Creek at County Road 338 & Elmore & 32.6300 & 86.1833 & Yes & 1 \\
\hline Cornhouse Creek at County Road 15 & Randolph & 33.2260 & 85.5411 & Yes & 1 \\
\hline Hillabee Creek at State Route 22 & Tallapoosa & 32.9846 & 85.8614 & Yes & 1 \\
\hline Hillabee Creek at Sanford Road & Tallapoosa & 33.0664 & 85.8805 & Yes & 1 \\
\hline Broken Arrow Creek at Harlan Road & Tallapoosa & 33.0753 & 85.9095 & Yes & 2 \\
\hline Josie Leg Creek at Lashley Road & Tallapoosa & 33.0023 & 85.8328 & No & \\
\hline Sandy Creek at County Road 34 & Tallapoosa & 32.7857 & 85.6842 & No & \\
\hline Emuckfaw Creek at State Route 49 & Tallapoosa & 32.9952 & 85.7492 & Yes & 4 \\
\hline Sweetwater Creek at Sweetwater Creek Road & Tallapoosa & 32.9922 & 85.6947 & No & \\
\hline \multicolumn{6}{|l|}{ Sites with no previous collections } \\
\hline Emuckfaw Creek at Hodgecreek Road & Clay & 33.1000 & 85.6833 & No & \\
\hline Tallapoosa River at Highway 46 & Cleburne & 33.6168 & 85.4738 & No & \\
\hline Dynne Creek at County Road 36 & Cleburne & 33.5642 & 85.5508 & No & \\
\hline Lochelooge Creek at County Road 5 & Cleburne & 33.5075 & 85.5691 & No & \\
\hline Chulafinnee Creek at County Road 8 & Cleburne & 33.5396 & 85.6283 & No & \\
\hline Fishhead Creek at Highway 431 & Cleburne & 33.5111 & 85.6429 & No & \\
\hline Verdin Creek at County Road 46 & Cleburne & 33.5667 & 85.4500 & No & \\
\hline Little Tallapoosa River at County Road 49 & Cleburne & 33.4947 & 85.3379 & No & \\
\hline Knokes Creek at County Road 10 & Cleburne & 33.5233 & 85.4086 & No & \\
\hline Hurricane Creek at County Road 15/26 & Randolph & 33.1752 & 85.5969 & No & \\
\hline Cohobadiah Creek at County Road 615 & Randolph & 33.4905 & 85.4618 & No & \\
\hline
\end{tabular}


upstream site was flooded behind a beaver dam and was inaccessible for sampling. Multiple fish were easily captured in the Hillabee Creek sites, Cornhouse Creek, and Elkahatchee Creek, as well as in Sofkahatchee Creek (J. Scanlan pers. comm.). One site, Sweetwater Creek, produced few fish of any species and showed evidence of severe stream degradation from timber harvesting.

Eleven sites with no previous Fundulus bifax collection records were sampled in an effort to find new stream populations (Table 1). Most of these sites were to the north of known sites in Cleburne County, Alabama, following the Tallapoosa River upstream towards Georgia in an attempt to find intermediate populations between the 2 known sites in Georgia and those in Alabama. Most of these sites showed obvious degradation from human uses, and none produced F. bifax. One site at the Tallapoosa River at Highway 46 was sampled and had the right habitat, including sandy substrate, but with heavy algal growth covering the sand. A site at the Little Tallapoosa River at County Road 49 was unsuitable habitat, with muddy water and deep unconsolidated sediments.

\section{DNA sequencing}

Sequences of the cytochrome $b$ mitochondrial locus were successfully generated from 10 Fundulus bifax from 5 sites. The same locus was also sequenced from an $F$. catenatus from the Paint Rock River in north Alabama, an $F$. stellifer from the Conasauga River in east Tennessee, and an F. escambiae from Alligator Creek in the western panhandle of Florida. F. escambiae was included as an outgroup. For analytical purposes, a sequence of 852 bases was used from all 13 fish, from position 30 to position 881 in the 1140-base gene. DNA sequences used are available through GenBank, accession numbers KC204750-KC204762.

\section{Tree building}

Fig. 2 shows a phylogenetic tree built using neighbor-joining with the HKY model and 1000 bootstrap replications. The 10 Fundulus bifax se- quences formed a shallow clade with $100 \%$ bootstrap support. F. stellifer rather than F. catenatus is weakly supported as a sister taxon in a clade with all of the $F$. bifax. Within F. bifax, there is weak support for a clade of 2 of the Elkahatchee specimens along with the only Channahatchee specimen, all on the southwestern edge of the species' known range..

Fig. 3 shows a phylogenetic tree built using MrBayes. This tree also shows Fundulus bifax as a shallow clade. A strongly supported clade of an Elkahatchee fish and the only Channahatchee fish is present, with 2 other Elkahatchee fish (1 and 4 in Fig. 3) slightly separated from all other individuals. $F$. stellifer is not in a clade with $F$. bifax, but is slightly more distant from $F$. bifax than $F$. catenatus in what is effectively an outgroup clade.

\section{Genetic distance}

$D$ was calculated among all 13 sequences. The range of distance between the 10 Fundulus bifax sequences was small, ranging from 0.000 to 0.018 . The one F. bifax that was consistently at the greatest distance from others sampled was the individual from Channahatchee Creek at the southwestern edge of the species' range, with a range of 0.008 to 0.018. The other 2 subgenus Xenisma species were further removed from $F$. bifax, with the distance between $F$. catenatus and all $F$. bifax sequences being 0.062 to 0.073 and that between $F$. stellifer and

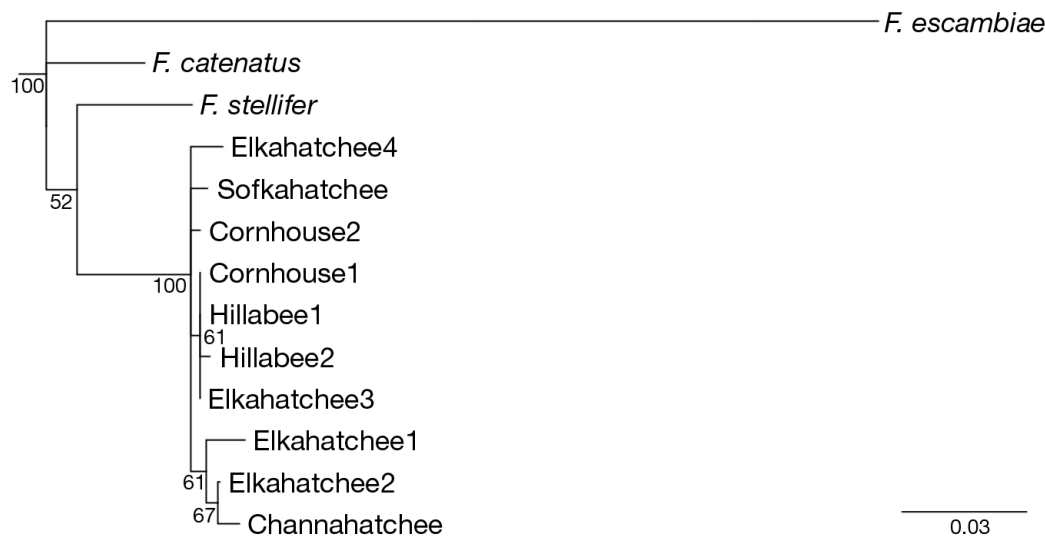

Fig. 2. Neighbor-joining tree with the HKY genetic model and 1000 bootstrap replications. Fundulus escambiae was designated as the outgroup. Channahatchee, Cornhouse, Elkahatchee, Hillabee, and Sofkahatchee are collection sites of $F$. bifax, numbers following site names refer to multiple individuals from those sites; $F$. catenatus and $F$. stellifer are the 2 species most closely related to $F$. bifax; $F$. escambiae is more distantly related. Numbers at nodes represent bootstrap support for the node. A distance scale (percentage of sequence divergence) is shown at the bottom 


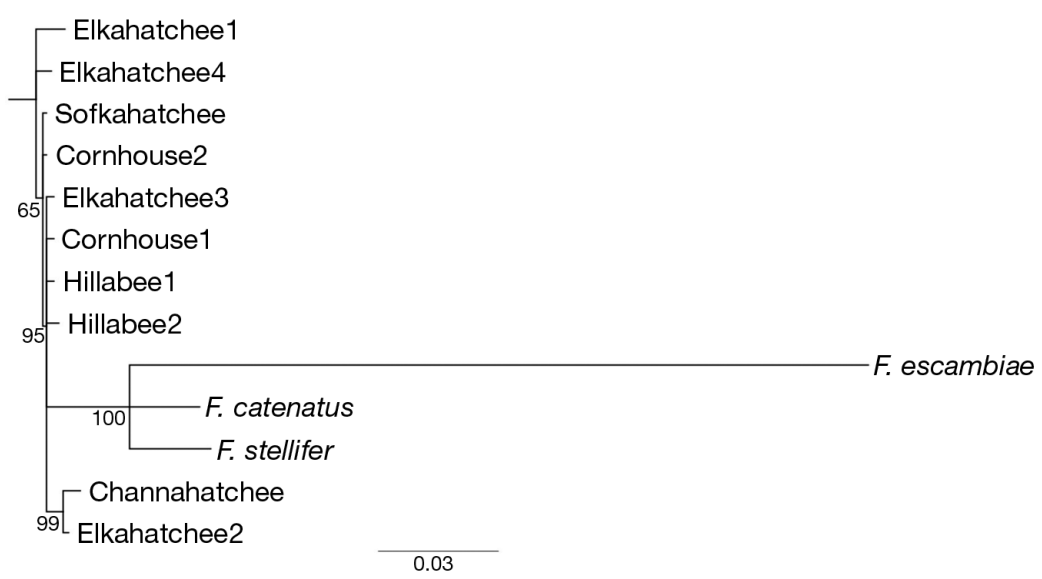

Fig. 3. Tree built using MrBayes with the GTR nucleotide substitution method, gamma rate variation, a chain length of 1.1 million, and subsampling frequency of 200. Numbers at nodes are percentage consensus support. Channahatchee, Cornhouse, Elkahatchee, Hillabee, and Sofkahatchee are collection sites of Fundulus bifax, numbers following site names refer to multiple individuals from those sites; $F$. catenatus and $F$. stellifer are the 2 species most closely related to $F$. bifax; $F$. escambiae is more distantly related. Node support is stronger than in the neighbor-joining tree only clear haplotype was of 3 fish that shared $\mathrm{T}$ at position 30 , and no other changes from the consensus sequence. These 3 fish were from different creeks, 1 each from Cornhouse, Elkahatchee, and Hillabee. The 2 sequences with the most substitutions were an Elkahatchee sequence with 12, and the Channahatchee sequence with 10 .

Analyzing all 13 sequences, the estimated value of the shape parameter for the discrete gamma distribution, $\alpha$, was 0.37. A value of $\alpha<1$ means that most nucleotide positions in the analyzed sequences have very low substitution rates, while a few sites exist with very high rates (substitutional hot spots; Tamura \& Nei 1993, Yang 1996). The nucleotide frequencies were $\mathrm{A}=$ $25.52 \%, \mathrm{~T}=33.62 \%, \mathrm{C}=25.66 \%$, and $\mathrm{G}=15.20 \%$.

\section{DISCUSSION}

all $F$. bifax sequences being 0.067 to 0.079 ; the distance between $F$. catenatus and $F$. stellifer was 0.056 . The more distantly related $F$. escambiae has a distance range from $F$. bifax sequences of 0.291 to 0.309 .

\section{Base substitutions}

Consistent with the low genetic distance values between the 10 Fundulus bifax, there were few base substitutions between different sequences. Of the 852 bases analyzed, only 25 were variable (Table 2 ). The
Fundulus bifax was found to have a range of 6 creeks, 5 of them tributaries to the Tallapoosa River and 1 tributary to the Coosa River in east Alabama (Fig. S1). The Tallapoosa River in this area has 2 dams and large reservoirs which both block easy dispersal and change riverine habitat to lacustrine. It is possible that some part of the Tallapoosa River that connects 5 of these creeks could provide usable habitat or at least a corridor between these creeks; the species was collected some years ago in the Tal-

Table 2. Fundulus bifax. Base substitutions of sequences from 10 individuals. Substitutions were present at 25 of the 852 base positions analyzed. The only clear haplotype is one shared by 3 fish with the consensus nucleotide $\mathrm{T}$ at position 30 , and no other substitutions. These 3 fish came from different creeks, 1 each from Cornhouse, Elkahatchee and Hillabee

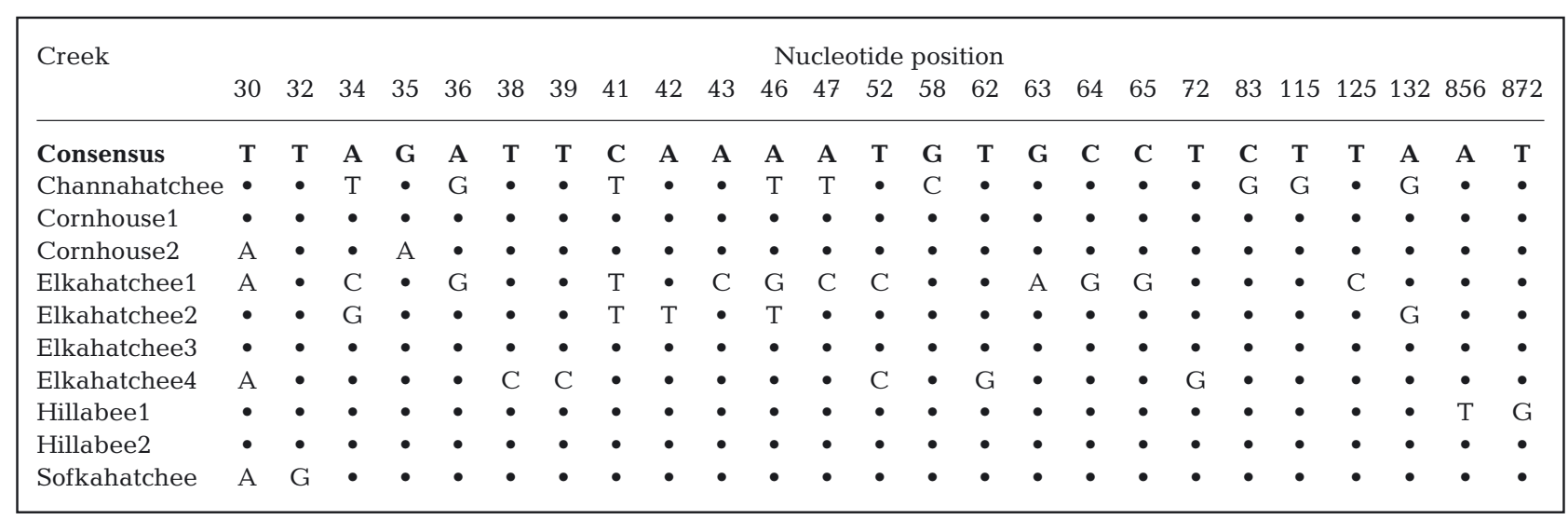


lapoosa River (S. J. Rider pers. comm.). The species has not been observed in Georgia since 1990 (Storey et al. 2003, see also http://georgiawildlife.com/sites/ default/files/uploads/wildlife/nongame/pdf/accounts/ fishes/fundulus_bifax.pdf), and efforts reported here failed to find either the fish or even suitable habitat for it in Cleburne County, Alabama, intermediate to historically known Alabama and Georgia populations. The Little Tallapoosa River also appears to be degraded habitat unsuitable for $F$. bifax, with a heavy sediment load and little clean sand necessary for successful spawning. The few known populations in the middle and lower Tallapoosa basin along with the 1 Coosa basin population currently define the species' range.

Four of the creeks in which Fundulus bifax was found appear to support healthy populations, based on ease of capture: Cornhouse Creek in Randolph County, Hillabee Creek in Tallapoosa County, Elkahatchee Creek in Coosa County, and Sofkahatchee Creek in Elmore County. A single fish was collected in Channahatchee Creek in Elmore County, and 2 fish were collected in Emuckfaw Creek in Tallapoosa County. All 6 of these creeks appear to be relatively pristine, with clear water and abundant clean sand that this species needs both for feeding and reproduction. These 6 creeks all run through relatively undisturbed land, with woodlands or well-managed farms making up much of their drainage.

Both phylogenetic tree-building methods used, neighbor-joining and MrBayes, resolved Fundulus bifax as a monophyletic clade with low internal genetic variation in the cytochrome $b$ gene. The only evidence of genetic variation and structuring was a clade of an Elkahatchee fish and the Channahatchee fish, from the southwestern edge of the species' current range. Unfortunately no genetic data are available for the extirpated Georgia population(s), so it may never be known what genetic diversity has been present in the species. Neither tree building nor analysis for $D$ showed either $F$. catenatus or F. stellifer to be clearly more closely related to F. bifax. Neighbor-joining placed F. stellifer in a clade with all of the $F$. bifax, but this was only very weakly supported, with bootstrap support of just over 0.5 . The range of values for $D$ between $F$. catenatus and F. bifax of 0.062 to 0.073 was slightly lower than that between $F$. stellifer and $F$. bifax, 0.067 to 0.079 . Small sample size precludes any strong conclusion about those relationships, but $F$. bifax was clearly differentiated from its 2 congeners. Interestingly, the genetic distance between
$F$. catenatus and F. stellifer of 0.056 shows them as being more closely related to each other than to $F$. bifax, which may be more remote from other Xenisma species than previously thought.

The population structures of 2 other Tallapoosa River endemics which have been studied previously offer a comparison for the possibility of higher historic genetic diversity in Fundulus bifax. The Tallapoosa darter Etheostoma tallapoosae is currently found from the Georgia headwaters of the river downstream as far as the fall line. Based on sequencing of the mitochondrial control region and cytochrome $b$ sequences, Brogdon et al. (2003) identified genetic structure within this species with at least 4 identifiable management units. Three of these management units are in the same area of the lower Tallapoosa basin as most of the F. bifax collections sites reported herein. The Tallapoosa shiner Cyprinella gibbsi, also with a current distribution from the Georgia headwater of the Tallapoosa River to the fall line, was found to have a similar population structure to E. tallapoosae based on the analysis of mitochondrial ND4L sequences (Connelly et al. 2006). This similar distribution of genetically distinct populations within these 2 species suggests that they share a common biogeographic history (Connelly et al. 2006). Although also a Tallapoosa endemic, F. bifax is more habitat-specific than these 2 species (author's pers. obs.), so it may have responded in different ways to historical changes in the Tallapoosa River basin. In particular, $F$. bifax requires extensive clean benthic sand for successful reproduction.

Fundulus bifax does indeed seem to be in a slow, steady decline in its range. Although apparently common in 4 streams, there appears to be little genetic diversity among these populations. Such low genetic diversity may make these populations less able to respond to future environmental perturbations through natural selection (Allendorf \& Luikart 2007). This threat from low genetic diversity is higher because these populations are now either largely or entirely isolated both through habitat fragmentation including the impoundment of the Tallapoosa River that historically connected most of them. The current conservation status of the species, N2N3 of NatureServe (imperiled/vulnerable) globally, S2 (imperiled) for Alabama, and Near Threatened with the IUCN, are very optimistic ratings because the species is apparently extirpated in Georgia and now has a range of much less than $5000 \mathrm{~km}^{2}$. The species needs more attention as a declining species than it currently receives. 
Acknowledgements. A. Adrian, T. Newby, and J Swarthout helped with field work. J. Scanlan also helped with field work, and contributed fish from Sofkahatchee Creek for DNA extraction. L. Larka at Oblique Bio was very patient with technical aspects of PCR and sequencing. K. Stanton modified code for the interactive site map. Birmingham Audubon largely supported this work with a research grant.

\section{LITERATURE CITED}

Allendorf FW, Luikart G (2007) Conservation and the genetics of populations. Blackwell Publishing, Malden, MA

Boschung HT, Mayden RL (2004) Fishes of Alabama. Smithsonian Institution, Washington, DC

Brogdon SM, Tabit CR, Kral LG (2003) Population structure of the Tallapoosa darter (Etheostoma tallapoosae). Southeast Nat 2:487-498

Cashner RC, Rogers JS, Grady JM (1988) Fundulus bifax, a new species of the subgenus Xenisma from the Tallapoosa and Coosa River systems of Alabama and Georgia. Copeia 1988:674-683

Cashner RC, Rogers JS, Grady JM (1992) Phylogenetic studies of the genus Fundulus. In: Mayden RL (ed) Systematics, historical ecology, and North American freshwater fishes. Stanford University Press, Stanford, CA, p 421-437

Connelly HM, Tabit RT, Kral LG (2006) Population structure of the Tallapoosa shiner (Cyprinella gibbsi) and the Tallapoosa darter (Etheostoma tallapoosae). Southeast Nat 5:85-92

Huelsenbeck JP, Ronquist F (2001) MRBAYES: Bayesian inference of phylogenetic trees. Bioinformatics 17: $754-755$

Editorial responsibility: Cornelius Hammer, Rostock, Germany
Irwin DM, Kocher TD, Wilson AC (1991) Evolution of the cytochrome $b$ gene of mammals. J Mol Evol 32:128-144 NatureServe (Hammerson G) (2010) Fundulus bifax. In: IUCN Red List of Threatened Species. Version 2012.1. Available at www.iucnredlist.org (accessed on 28 June 2012)

Pääbo S (1990) Amplifying ancient DNA. In: Innes MA, Gelfand DH, Sninsky JJ, White TJ (eds) PCR protocols: a guide to methods and applications. Academic Press, San Diego, CA, p 159-166

Scanlan J (2008) Notes on the captive spawning of Fundulus bifax. Am Currents 34:9-11

Storey JC, Straight CA, Freeman BJ, Peterson J, Irwin ER, Freeman MC (2003) Distribution of endemic and imperiled fauna of the Tallapoosa River System of Georgia. In: Hatcher KJ (ed) Proc 2003 Georgia Water Resources Conference, April 23-24, 2003 University of Georgia. Institute of Ecology, The University of Georgia, Athens, GA

Tamura K, Nei M (1993) Estimation of the number of nucleotide substitutions in the control region of mitochondrial DNA in humans and chimpanzees. Mol Biol Evol 10: 512-526

Tamura K, Peterson D, Peterson N, Stecher G, Nei M, Kumar S (2011) MEGA5: Molecular Evolutionary Genetics Analysis using maximum likelihood, evolutionary distance, and maximum parsimony methods. Mol Biol Evol 28:2731-2739

Warren ML Jr, Burr BM, Walsh SJ, Bart HL Jr and others (2000) Diversity, distribution, and conservation status of the native freshwater fishes of the southern United States. Fisheries 25:7-29

Yang Z (1996) Among-site rate variation and its impact on phylogenetic analyses. Trends Ecol Evol 11:367-372

Submitted: September 28, 2012; Accepted: November 14, 2012 Proofs received from author(s): January 30, 2013 